European Journal of Cultural Studies

\title{
Transnational representation of a gendered recession in corporate dramas
}

\author{
Elena Oliete-Aldea
}

Universidad de Zaragoza, Spain

\begin{abstract}
The cinematic depiction of the financial crisis has centred on the explanation of the causes and consequences of the global recessionary scenario in which gender acquires special relevance. My aim in this article is to carry out a hitherto unaddressed transnational analysis of corporate dramas. More specifically, l elicit the commonalities as well as local specificities that different Western cinematographies show when tackling gendered recessionary discourses on 'mancession' and 'austerity'. Films such as The Last Days of Lehman Brothers (Samuels, 2009, BBC), Money Never Sleeps (Stone, 2010), The Company Men (J. Wells, 2010) and The Big Short (McKay, 2015) have, on the one hand, aligned with nostalgic and retro-sexist discourses by focusing on male suffering to confront the recession while relegating female characters as emotional companions of the male hero. On the other hand, the representation of female characters in these films has also put to the test the inconsistencies of neoliberal discourses when analysed from the perspective of genre. To illustrate the transnational dimension of the 'narrated' impact of the 'Global Financial Crisis' in different scenarios, I compare a US Wall Street film and a Spanish corporate drama of the Great Recession: Margin Call (J Chandor, 2011, USA) and The Tip of the Iceberg (La punta del iceberg, D Cánovas, 2016, Spain).
\end{abstract}

\section{Keywords}

Corporate drama, gender, global financial crisis, neoliberalism, transnational cinema

\section{Introduction}

The 15th of September 2008 officially marked the date of the financial crash. One of the most powerful banks in Wall Street filed for bankruptcy causing a tsunami of financial

\section{Corresponding author:}

Elena Oliete-Aldea, Departamento de Filologia Inglesa y Alemana, Facultad de Economía y Empresa, Universidad de Zaragoza, Gran Vía 2, 50005 Zaragoza, Spain.

Emails: eoliete@unizar.es; ely.oliete@gmail.com 
collapse that swamped global markets. It was regarded as a 'pivotal moment of change' that indicated the beginning of the recession era. ${ }^{1}$ The fall of Lehman Brothers constitutes a synecdoche of the complex scenario brought about by the financial crisis in the United States, which soon reached the heart of advanced capitalist economies worldwide. This 'turning point' originated by the Global Financial Crisis led to the Great Recession, which entailed economic hardship for hitherto optimistic capitalist economies across the Atlantic. The new recessionary scenario revealed a series of latent crises and inconsistencies which questioned the neoliberal myth of progress, development and freedom of choice. Much has been already debated on whether the use of the term 'crisis' is an accurately descriptive word which accounts for the real events or has become a socially constructed 'blind spot' used to enforce undemocratic measures on the population (Klein, 2017; Roitman, 2016). ${ }^{2}$

Bauman and Bordoni (2014) have described the contemporary conjuncture as a 'divorce between power and politics'. According to them, supranational forces impede local political agencies to implement effective measures that would palliate the devastating effects of the crisis on vulnerable local communities. Such a context of paralysis and lack of agency in the political sphere at a State level has favoured the adaptive forces of neoliberalism to mutate from the cause to the solution of the problem. Cultural and political narratives of the crisis in the media have also contributed to present neoliberal policies as the only way out of this impasse, following Thatcher's 'There Is No Alternative' (TINA) discourse of the 1980s. In Colin Crouch's (2011) words,

Whereas the financial crisis concerned banks and their behaviour, resolution of the crisis has been redefined in many countries as a need to cut back, once and for all, the welfare state and public spending. And the issue today is not limited to a single country, as neoliberalism is an international, even global, phenomenon. What we have to understand today is, therefore, the strange non-death of neoliberalism. (p. viii)

Different types of 'crises' have thus intersected in the paradigm of the New Millennium. Sylvia Walby (2015) indicates that the interconnectedness of the economic, political and social systems within and between countries in the era of globalization has allowed the crisis to cascade through society: first in finance, then a recession in production and employment and, finally, a fiscal crisis leading to a political and democratic crisis (p. 2). The narration of the crisis has thus shifted its focus from the financial origins of market deregulation to a fiscal crisis that compelled governments to implement austerity measures. In spite of its global scope, the 'crisis' has materialized differently depending on the particularities of each local scenario across the Atlantic. Likewise, the discourses arising from the narrativization of the crisis have been shaped diversely depending on the conjuncture; and yet, they have also intersected in terms of class, gender, sexuality, ethnicity and national identity across different communities.

According to Walby, the movement from financial to austerity crisis had specific gendered implications since women have been targeted as one of the most vulnerable groups affected by welfare cuts. Gill (2017) also claims that 'an analysis of gender is central to understanding the current moment'. The Great Recession has thus revealed a conflictive scenario in which the neoliberalism-postfeminism tandem has also adapted its narrative 
of individualistic 'choice' to the new austerity circumstances. Postfeminist discourses also overlap with the rising of fourth-wave feminism, which, at the same time, cohabits with a gender backlash and increasing misogyny (Gill, 2017; McRobbie, 2009; Negra and Tasker, 2014; Rivers, 2017; Thouaille, 2018). In this complex scenario, Arruzza et al. (2019) distinguish between a liberal, corporate feminism, which is regarded as a handmaiden of capitalism, and what they call 'feminism for the 99\%'. The latter intersects with other movements of social protest which emerged on the eve of the financial crash to condemn the growing inequality gap between the superrich and the precariat at a global scale.

As a cultural product, cinema has attempted to represent this complex panorama through a cycle of films that tackle the 'crisis' from different angles. On the one hand, the chameleonic nature of neoliberalism has extended its pervasive influence as the only alternative to the crisis across the Atlantic. On the other hand, critical voices have emerged in local contexts in which precarity has hit vulnerable social groups and individuals. The global 'recessionary culture' stemming from the crisis has also allowed the emergence of new cultures of connectivity which share a common criticism against the TINA discourse through typically indigenous but also transnational modes of filmic representation.

In this article, I will try to unveil the complex narratives that have shaped the recessionary discourses in terms of gender. More specifically, I will focus on the transnational dimension of a cycle of US and European films which have dealt with the financial crisis. My aim is to demonstrate how corporate dramas of the crisis have laid bare the inconsistencies of neoliberal practices when observed through a gendered lens. ${ }^{3}$ By exposing the global impact of the financial crisis on local scenarios, the films help to draw lines of common experiences of vulnerability and precarity across borders while simultaneously addressing the particularities of their own recessionary context. In order to tackle the transnational dimension of the "narrated' impact of the 'Global Financial Crisis' through different modes of cinematic representation, I will compare the portrayal of female characters in the US film Margin Call (Chandor, 2011) and the Spanish The Tip of the Iceberg (La punta del iceberg, D. Cánovas, 2016, Spain).

\section{Gendered narratives of the financial crisis across the Atlantic}

In spite of the particularities of the different Western economies on both sides of the Atlantic, the global scope of the crisis also shared certain transnational 'shock' narratives. The financial crash has frequently been portrayed in the United States and Europe as a catastrophe that could only be palliated by implementing unpopular measures, which included bailing out certain banks while imposing austerity measures on society (Klein, 2017). For all the responsibility placed on financial institutions as the main originators of the crisis and subsequent recession, certain discourses in the media diverted the attention towards the unsustainability of the welfare state, especially in European countries.

One of the discourses which acquired strength in the United States was the so-called 'mancession'. The term appeared in 2009 in blogs such as that of Mark Perry, and the 
popular press with the controversial article 'The End of Men' by Hanna Rosin (2010). The Organization for Economic Cooperation and Development (OECD, 2010) also mentioned it when describing unemployment figures. 'Mancession' refers to the fact that unemployment hit men dramatically while it merely affected women. ${ }^{4}$ This led to a masculinity crisis, since the 'breadwinner' role was replaced by that of 'househusband', who had to perform traditionally 'feminine' activities - still regarded by some as 'diminishing for men' (Negra and Tasker, 2013: 345-346). Peterson (2012) notices that many commentators in the media established a direct relationship between male unemployment and a decline in their power and status (p. 280).

It cannot be denied that unemployment particularly hit the male population: the truth is that the crisis was particularly virulent in (White) male-dominated jobs, both in the construction and financial sectors. Of course, the recession impinged on women and minority groups too; however, the media's attention was mainly drawn to those privileged middle-class White men who were not used to precarity. More importantly, the 'mancession' narrative presented the loss in male jobs not as one more repercussion of the economic crisis but exclusively as a consequence of female empowerment. The zerosum logic of this narrative is actually grounded in 'larger cultural and economic anxieties' related to the changing roles in terms of gender and sexuality in the last decades (Peterson, 2012: 281).

Peterson argues that the idea of 'mancession' as a zero-sum battle of victors and victims has its roots in a long-standing vision of capitalist economies which separate the 'public' and 'private' spheres to construct a social hierarchy that favours the former against the latter. Such dualism also sanctifies market economy while devaluing alternative forms of provisioning such as non-wage labour in the private sphere, usually associated with women. Consequently, women - and men performing roles in the private sphere - have therefore been devalued as 'non-economic persons' (Peterson, 2012: 284).

Various economic studies show that women were also highly impacted by the recession, not only in terms of unemployment but also of job precarity (Coontz, 2012; Peterson, 2012). Negra and Tasker point out how the dominant recessionary discourses have polarized gender principles even further, arguing adamantly against the idea of a 'feminine' welfare state. Derogatory 'feminine' expressions in the descriptions of the current socio-economic scenario are frequently used and the 'nanny state' continues to be caricaturized, while expressions such as the invitation to 'man up' to overcome the recession proliferate (Negra and Tasker, 2014: 2). The discourses on 'mancession' therefore helped reinforce neoliberal values of the market based on ruthless competition and entrepreneurship; these ideas are embedded within a social Darwinist framework, traditionally associated with 'masculinity'. In contrast, social values of equality and care provided by public services tend to be regarded as 'feminine'.

While the discourses of 'mancession' spread mainly in the US media - and, to a certain extent, in the United Kingdom - the crisis in European countries tended to focus on the unsustainability of the welfare state and the burden of Mediterranean countries on the stronger economies in the European Union. Even though the rage against women emanating from the 'mancession' narrative was apparently absent in Europe, anger was precisely directed towards PIGS countries, often described as idle dependants of subsidies. In the case of Spain, attention was driven towards the unsustainability of the welfare 
state with an increasingly ageing society in need of pensions, a rate of unemployment surpassing 20 percent and expensive public healthcare and education systems. Furthermore, public employees with permanent jobs contributed to the lack of flexibility of the Spanish labour market (De Espinola Salazar, 2009). ${ }^{5}$ The so-called 'Spanish miracle' of the previous decades came to an end when the global financial crisis revealed the excessive accumulation of debt in the Spanish economy, representing one of the 'greatest real estate bubbles in the world' (García Delgado and Myro, 2014). Spain becomes thus a clear example of how the narrativization of the crisis shifted its focus from the risky capitalist practices of the mortgage bubble to public debt.

In 2011, the solution for the recently elected conservative government was to cut public expenses. This entailed a worsening of female labour conditions, as cuts in the welfare system intensified the work of women as carers for less or no pay (Walby, 2015: 85). ${ }^{6}$ Furthermore, a labour reform was passed with the intention of making the market more flexible and hence more competitive for businesses (García Delgado and Myro, 2014). ${ }^{7}$ Measures included in this reform were the reduction of firing costs and changes in labour conditions for reasons of competitiveness or productivity. The result was that bargaining power shifted dramatically from employees to employers, which put workers in general and women in particular, in a vulnerable situation (Dolado, 2012; Lombardo, 2017).

In Spain, the percentage of women working in the public sector has always been much higher than that of men. ${ }^{8}$ Consequently, not only were their salaries lowered but so too were also the number of positions available. Moreover, the conservative government and the media launched a campaign to discredit public employees as idle workers in a jobfor-life position who were not contributing to society's growth as opposed to hard-working entrepreneurs in the private sector (Alonso et al., 2016). Considering the high female presence in the public workforce, the discursive disparagement of public employees implicitly had gender connotations. The aim of such discourses was not only to justify the austerity measures as well as the labour reform, but also to divert attention away from the foreclosures executed by banks. Paradoxically these banks were being rescued with tax-payers' money. Although such discourses were not expressed in gendered terms, the truth is that the public-private narrative divide was intended to favour neoliberal discourses of competition and entrepreneurship while disparaging the traditionally conceived 'feminine' caring work of the 'nanny' state (Nuño, 2009).

The intersectionality of all these discourses is present in the films produced on both sides of the Atlantic that portray recessionary scenarios from different generic and filmic angles. Apart from documentaries - such as Capitalism: A Love Story (M. Moore, 2009), American Casino (L. Cockburn, 2009), Inside Job (C. Ferguson, 2010) and The Flaw (D. Sington, 2011), among others - many fiction films have included the crisis in their narratives as the main plot or as a secondary but relevant thread. It seems that most filmmakers have found in social realist dramas their main vehicle for expressing their views in the so-called 'Austerity films' especially in European cinematographies - some examples are Loach's I, Daniel Blake (2016, UK), Two Days, One Night (Deux jours, une nuit, J.P. Dardenne, L. Dardenne, 2014, Belgium, France, Italy) and Food and Shelter (Techo y Comida, J. M. del Castillo, 2015, Spain). It is also true that comedy, horror, thriller and science-fiction are generic conventions widely used in recessionary films, such as Drag 
Me to Hell (S. Raimi, 2009, USA), Off Course (Perdiendo el Norte, N. G. Velilla, 2015, Spain) and Assault on Wall Street (U. Boll, 2013, Canada, USA), to name but a few. ${ }^{9}$

The corporate drama sub-genre, though, is the one that predominates when framing the narratives of the financial crisis on screen. Following a tradition of Wall Street films - most conspicuously Wall Street (O. Stone, 1987) - or business movies such as Glengarry Glen Ross (J. Foley, 1992), the US corporate dramas of the crisis are mainly male melodramas which focus on the professional and personal experiences of White male financial executives in the event of the financial meltdown. By privileging White male suffering over other crisis-hit sectors of society, such cinematic response recalls the discourses on 'mancession'. During the first years after the crash, there were mostly documentaries, docudramas and realist films trying to explain the origins and development of the crisis, which constitute a cycle of Financial Crisis films: Up in the Air (Reitman, 2009), Money Never Sleeps (Stone, 2010), The Company Men (Wells, 2010), Margin Call, Too Big to Fail (Hanson, 2011, HBO) and Arbitrage (Jarecki, 2012). A few European movies also tackled similar plots: Freefall (D. Savage, 2009, BBC, UK), The Last Days of Lehman Brothers (Samuels, 2009, BBC), Capital (Costa-Gavras, 2012) and The Tip of the Iceberg. According to Ho, other movies were subsequently made, which dealt with the excesses of finance in a less realist and more parodic vein, such as Cosmopolis (Cronenberg, 2012), The Big Short (McKay, 2015), The Wolf of Wall Street (Scorsese, 2013) and The Wizard of Lies (Levinson, 2017).

These corporate dramas depict a male-dominated world, which reflects the glass ceiling women face when entering the financial labour sector. The presence of female characters in these films tends to be reduced to three main roles: gold-diggers - who are sexual objects for the male executives' pleasure-, faithful wives and mothers who -support the troubled male hero- and top executives, who have apparently broken the glass ceiling by becoming 'masculinized' characters complicit with the liberal-feminist idea of 'equality opportunity in domination' (Arruzza et al., 2019). One of the narrative elements that characterizes the US Financial Crisis films is a nostalgic harking back to pre-crisis times, more specifically to the booming period of the American economy of a Fordist type of capitalism, that is, the 1950s and 1960s. A recurrent trope is the constant evocation of the traditional family structure as a shelter for individuals hit by the crisis, especially for unemployed male characters that embody the 'mancession' discourse. Male and family melodramas such as The Company Men, Money Never Sleeps and Freefall use the contraposition 'home' versus 'house' to metaphorically represent the mortgage meltdown and its implications: empty houses with a foreclosure sign symbolizing social downfall as a consequence of individual greed. This is set against the longing for a comforting home to find shelter in the midst of the crisis. The family is portrayed as the victim of greedy investors, while it is also presented as the only antidote to heal the wounds of the crisis (Kinkle and Toscano, 2011: 45).

On the one hand, this sense of community, symbolized by the family, contributes to criticize the dehumanizing process of neoliberal policies, which promote individualism and deregulation of the economy with its consequent devastating effects on society at large. On the other hand, the use of the family melodrama and, more specifically, male melodrama, has further implications in the representation of gender roles. It is true that most female characters in the above mentioned films are portrayed as empowered 
women, both economically and emotionally. Nevertheless, the nostalgic harking back to the traditional family structure reinforces the need for these male characters affected by 'mancession' for a woman who embodies the traditional feminine roles of care and emotional support that maintains the family united.

Such portrayal of female characters in these films actually recalls what Susan Faludi (2006) described as backlash in the 1980s. A parallel could thus be established between the representation of women in corporate and Wall Street films of the 1980s and 1990s with those in the financial crisis films of the first decades of the New Millennium: according to Tasker, films such as Baby Boom (Shyer, 1987), Wall Street (Stone, 1987) and Working Girl (Nichols, 1988) show an ambivalent portrayal of working women, who become economically independent characters, but who are associated with a heterosexual 'feminine' sexuality and behaviour (Tasker, 1998: 39-43). Their incursion in the public sphere is thus welcome as long as they keep their traditional femininity in the private sphere and remain in a secondary position with respect to male characters.

In Financial Crisis films, female characters are valued if they retain the above mentioned roles and are generally vilified or sacrificed if they become 'too masculinized' when entering the public sphere. These movies, thus, portray a version of 'femininity' that aligns with the neoliberalism-postfeminism tandem. As Rosalind Gill (2017) explains, the ideas of individual choice and empowerment by self-surveillance have formed part of a hegemonic discourse present in everyday life. Thanks to their capacity of adaptation to new contexts, these ideas prevail even in recessionary discourses, blaming personal failure on lack of self-confidence and insufficient individual work instead of structural inequalities (Gill, 2017: 618). Apart from the meritocratic fight to lean-in and break the glass ceiling advocated by liberal feminists, a postfeminist discourse also emphasizes the construction of a pleasing, approachable type of femininity which demonstrates a resilient individuality against difficulties and is, in sum, patriarchy-friendly (p. 619). Corporate dramas of the crisis apparently align with this representation of postfeminist sensibility: a successful professional woman who is either pleasing in character or punished if her behaviour is too aggressive and thus patriarchy-threatening. Several fractures, though, appear in such a representation, since this portrayal of women eventually reveals itself as an artificially imposed masquerade, showing the contradictions of not only the neoliberal discourse of individual choice and meritocracy but also of the postfeminist empowerment via physical and psychological self-surveillance.

Set in financial environments, these films show the perpetuation of the glass ceiling in an almost all-male cast of financial executives. The few female characters that hold these roles are usually devoid of traditionally 'feminine' attributes in an attempt to be accepted as an equal in a male world. Paradoxically, these women need to retain a 'heterosexual feminine' look while 'manning up' in order to break the glass ceiling; however, their behaviour is vilified as they are shown as 'anti-natural' women in their individualistic and competitive conduct as opposed to men's. They are thus judged with a double standard that still sexualizes the private and public spheres. On the other hand, if they accept their traditional non-patriarchy-threatening 'feminine' roles, they will be relegated to a position of inferiority in the devalued private sphere. 


\section{Gender performativity and masquerade in corporate dramas of the crisis}

Together with Too Big to Fail and The Last Days of Lehman Brothers, Margin Call could be interpreted as one of the fictionalized versions of the many documentary films produced after 2008. After one of the worst periods of economic uncertainty and depression in the United States, 2010 started to witness a shy recovery only to be followed by a period of recession (Blinder, 2013). The release of Margin Call in 2011 almost coincided with the Occupy Wall Street movement, which denounced the harsh consequences of the crisis for the 99 percent. It was not until 2012-2013 that narratives announcing the 'end of the crisis' started to gain force, even so, according to Tooze (2018), such 'recovery' only represented mutation and metastasis of a new world order that emerged after what he calls the first crisis of globalization. ${ }^{10}$

Disenchantment and lack of hope are, therefore, the main features that characterize these films. As opposed to previous 'Wall Street movies', which were constructed as 'morality tales', often in the form of bildungsroman, 21 st century financial films show a world in which ethics has been completely disentangled from finance, with an economic system benefitting only those on top of a new plutocratic world order (Parvulescu, 2018). ${ }^{11}$ Inspired by the events preceding and following the financial crash of 2008 in firms such as Lehman Brothers or Merrill Lynch, Margin Call depicts the decision-making process on the part of the management of an investment bank when a young risk analyst discovers that the company is on the verge of bankruptcy. With only one woman out of six characters playing the leading role in the top management position of the firm, the film reproduces the actual underrepresentation of women at the top positions in the world of business and finance. The lack of gender diversity has promoted the hegemonic 'masculine' financial culture or 'bro culture' which encourages 'group think' and 'herding' rather than 'critical thinking' (Walby, 2015: 58). This type of male subculture in financial centres is 'linked to a propensity towards high levels of risk taking and short term thinking' (McDowell in Walby, 2015: 58; Ho, 2009, 2018; Luyendijk, 2015).

According to Karen Ho (2018), docudramas of the crisis 'demonstrate the extent to which the financial elite work within their "innetworks", forged and solidified through bonds of whiteness and masculinity, to plan and structure market action and make deals' (p. 103). This gendered approach to the depiction of Wall Street is indirectly depicted in Margin Call. The lack of female voices in the decision-making process is patent in the film when the risk analyst Sarah Robertson (Demi Moore) is chosen as a scapegoat and only male figures remain in the leading positions of the firm. It is interesting that Sarah is sacrificed in spite of her effort to look, act and behave like her male counterparts; she reveals a competitive aggressive attitude which is often associated with the 'masculine' corporate world. ${ }^{12}$ Like her male colleagues, Sarah's actions are driven by greed for wealth and power, as well as fear of symbolically falling from the top position in the company.

Sarah's colleague at the Risk Analysis Department, Eric Dale (Stanley Tucci), who is fired from the firm earlier, suspects that she has betrayed him, just to remain on top. Sarah's fear of falling is confirmed in a subsequent scene with her colleague Jared Cohen (Simon Baker) in an elevator, where she nervously expresses that she is afraid of being 
expelled from the company and she threatens Jared that if she falls, they will do it together. Nevertheless, as a metaphoric fast-forward, she gets out of the lift while Jared remains. She steps out of the elevator together with a cleaning lady, paralleling their situation as women being expelled from the corporate space; of course, Sarah's severance pay and benefits after quitting will leave her in a far better place than the cleaning lady's eventual situation as an unemployed person. Negra and Tasker argue that corporate melodramas such as Margin Call, The Company Men and Arbitrage represent workplace frustration for men who are victimized by corruption, conspiracy or redundancy, the corporate world becoming a place of power and authority but also a source of anxiety. However, "these scenarios remain unwilling to cede positions of authority to women. Thus, it is female executive Sarah, rather than her male counterpart Jared, who is sacrificed in a reckoning with the markets in Margin Call' (Negra and Tasker, 2014: 16).

Sarah's coldness, together with the tension of her facial expression, does not allow the audience to feel sympathy for her, except when the CEO, John Tuld (Jeremy Irons), informs her that she is going to be dismissed: she stands in front of her desk which shows a kind of toy and a frame with the picture of a person, probably a relative. This subtle connection with human bonding may raise in the spectator a feeling of pity for her, as she is granted some humanity which she had hitherto concealed under her 'corporate masquerade'. In that scene, she is shown against a background of computer screens, her face showing anger and her tight lips repressing her thoughts and feelings. John commands her not to fight him, and she has no other choice but to keep quiet and accept her fate as being 'the head' instead of Jared. The darkness of the office is disrupted by a red lamp and notebook, denoting a melodramatic spark of repressed emotions amid the sobriety of the corporate mise-en-scène. Only when the CEO leaves is Sarah finally allowed to breathe deeply back into humanity.

In a subsequent scene, Sarah is portrayed in light-coloured loose clothes and loose hair. In opposition to her previous look, this new image portrays Sarah as a relaxed person, freed from the constrictions of the 'masculine masquerade' which had been imposed on her. She is sitting next to the window and she shown from a high-angle perspective, which gives the impression that she is getting closer to the street. As it begins to get light at sunrise and her dismissal approaches, Sarah's facial expression evolves from anguish to acceptance and even relief. When Eric enters the room and both of them wait for the severance conditions after quitting the firm, Sarah shows concern for him, asking for his children and even apologizing to him for his dismissal, with the recurrent excuse that she had no choice. Opposing the discourses of 'mancession' or 'crisis of masculinity', the film actually reveals a crisis of 'femininity', understood discursively as the caring values of a welfare system. It unmasks the fact that the aggressive and greedy principles of an unregulated free market transfer risk from the top to the bottom of the social system, leaving the weaker ones unprotected. It could therefore be said that society, in the same way as Sarah, is in need of those 'feminine/social values', whose repression has provoked the tragic outcome of the crisis.

This gendered interpretation of the global financial crisis is also portrayed in The Tip of the Iceberg, a recessionary corporate drama set in a multinational company in Spain. Contrary to Margin Call, The Tip of the Iceberg does not form part of a cycle nor follow a tradition of financial films. ${ }^{13}$ According to Beale (2010), Hollywood has tended to 
portray the crisis in financial scenarios, rather than the consequences of the recession for the 99 percent. In contrast, Spanish - and European - films have developed a cinema of precarity, showing the consequences of the austerity crisis on the population. Released in 2016, The Tip of the Iceberg was based on the homonymous play by Antonio Tabares, which was premiered in 2011. The years 2010-2011 witnessed Europe's sovereign debt, which impacted even harder on the European economies that had already been affected by the 2008 crash. PIIGS economies were particularly hit, Spain being bailed out in 2012. As explained above, the Conservative government mandate (2011-2018) brought about years of austerity with cuts in public services, foreclosures with massive evictions and the implementation of the labour reform. It is during that time that the greater number of Spanish austerity films were released. Labour precarity, social vulnerability, an increase in the suicide rate related to the practice of evictions became the plots of Spanish 'cinema of precarity' (Allbritton, 2014). As a corporate drama, The Tip of the Iceberg departs from the generic conventions of social realist films; nevertheless, the film indirectly focuses on the precarious scenario of Spanish society.

The main character, Sofia Cuevas (Maribel Verdú), is a businesswoman who works in the headquarters of a company and is sent to a subsidiary to investigate the suicides of three employees in the building. From the very beginning, the film carefully portrays her as a 'masculinized' woman who had to forsake her 'femininity' in order to climb the predominantly male company hierarchy. She is also shown to be aggressive and competitive yet, like Sarah, her performance reveals that she is playing a role in her cross-dressing performance as a top executive. Her facial expression is always tense, she nervously needs to smoke after she has to act mercilessly 'bossy', and is shown as relieved when coming home after work, loosening her tight hair, taking off her suit and dressing up in colourful loose clothes.

The company subsidiary is set in a suffocating building which seems to imprison the company's employees inside. Similar to Margin Call, cold bluish colours predominate in the mise-en-scène. Also, part of the narrative takes place at night; consequently, a dark atmosphere enhances the claustrophobic feeling of the employees trapped in the building. As in Margin Call, the trope of 'falling from the top' permeates the whole narrative. There are two similar scenes that take place in the rooftop of the building. In Margin Call, Will Emmerson (Paul Bettany) and two junior executives go up there to smoke. Will sits on the edge of the railing and ironically states that people are not afraid of falling but afraid that they may want to jump. He actually has no intention of jumping as he is a survivor in the capitalist system who unscrupulously steps on others' heads in order to save his position in the firm and privileged status in society.

In The Tip of the Iceberg, Gabriela Benassar (Bárbara Goenaga) is an employee who usually goes to the rooftop to have lunch. She used to be the secretary of one of the executives who committed suicide. It turns that she had an affair with him and got pregnant, but decided to have an abortion fearing that she could be a victim of mobbing, as was the case with other pregnant women in the company. She also looks down from the edge and, as with Will in Margin Call, says that there is an attraction to jump into the void; nonetheless, in contrast to Will, she eventually jumps after giving Sofia a pen-drive with information about the company's malpractice. She becomes the fourth employee to die by suicide in the building. This is the turning point that makes Sofia take the decision 
to denounce the company's misconduct. Instead of covering up the suicides as the outcome of personal trouble, as she was asked to do, she reveals that the head of the subsidiary, apart from exploiting the employees with stressful deadlines, secretly recorded them with cameras in the offices in order to blackmail them and make them work even harder.

Sensitive to the context of austerity in which the rate of suicide increased dramatically, ${ }^{14}$ the film is also critical of the Spanish recessionary context in which the labour force, especially women, had become more vulnerable to precarity due to the labour reform. Perhaps the fact that, after having an abortion for fear of losing her job, a young woman decides to put an end to her own life makes Sofia reflect on the dehumanizing effect the company has on the employees and on herself. At some point in the film, we learn that she used to be a creative designer who abandoned her vocation to become a successful businesswoman. She decided not to have children in order to be promoted. The audience also infers that she had split up with her boyfriend because of her workaholic condition. The fact that her ex-boyfriend was a biologist symbolically reflects the way her devotion to the company has cut her only bonds to life, nature and humanity. A parallel could be established with the character of Sam Rogers (Kevin Spacey) in Margin Call when he literally and symbolically buries his dog in tears, which represented his only bond of affection. Sofia's 'masculinized' performance is thus represented in the film as anti-natural for a woman. She even contributes to the dismissal of her own sister-inlaw by writing a report on her poor performance. Paradoxically, in spite of her personal sacrifices, as well as her physical and psychological self-surveillance, she has not been empowered enough to reach the top of the company hierarchy. The board of directors is shown to be composed exclusively of men and several scenes show her literally and symbolically looking up at the glass ceiling of the company building.

The film's originality is that the narrative does not limit that 'unnatural behaviour' to women. Although it is true that the top managers seem to be at ease with their dehumanized behaviour, the suicides of male employees prove that men could not comply with the social Darwinist ethos of the company, either. Even the two male characters that embody the competitive values of capitalism are actually shown to be performing an imposed role, just like Sofia and Sarah. First of all Carlos Fresno (Fernando Cayo), the head of the subsidiary, is presented as a ruthless director who does not care about the personal problems of his stressed employees as long as productivity in the company increases. He seems to be a cold, dehumanized man. He is shown in his grey office, with a conservative suit and a cold blue shirt, yet he wears a red tie, which contrasts with the coldness of the scenes in which he appears. Just as in Margin Call, the disruptive red colour symbolizes repressed emotions, indicating that there is something wrong in the apparent cold and bluish sobriety of the setting. The audience later learns that he has personal problems which he leaves aside when entering the corporate building: every night after work he goes to the hospital to visit an ill young woman, probably his daughter, which confers a spark of humanity to this character. He thus seems to be acting out an imposed role in the firm, where he is also working under pressure due to the standards dictated by the management.

During her inquiry, Sofia also meets Jaime Salas (Álex Garcia), a young man who seems to be happy with the rules set in the company by Fresno. He says that capitalism is a system based on ruthless competition in which only the fittest may survive. In his 
conversation with Sofia, he uses sexualized and sexist expressions when referring to the capitalist system: he describes Fresno as a man who 'has got balls', that, in the midst of the crisis, companies have to 'man up' and that he is actually sexually aroused by this ruthless competitive system: 'capitalism turns me on', he says. However, the audience later learns that he is also acting out his role as a capitalist-lover. In a subsequent scene, he meets Sofia again in the basement, where he only has time for a chocolate bar from the vending machine for lunch. He says he likes going to this place because the wall is painted with a landscape of a paradisiac beach. It is like a desperate search for nature by employees while trapped in the artificial corporate building. He is shown to be stressed out and also concerned about the suicide of his colleagues. His cards are finally shown when he sends a message to Sofia with the phone number of a journalist, indirectly encouraging her to publicly denounce the company's situation to the press.

While characters in Margin Call cling to their privileged status and make individualist decisions to save themselves, Sofia gradually takes off her 'mask'. She personally interviews the company's employees face-to-face and understands that all of them comply to the rules of the system out of fear of being fired and unable to find a new job in a country hit by the crisis. Even though Sofia is also sacrificed as a scapegoat by the top management, she is not presented as a mere victim, as Sarah is. Sofia deliberately chooses to be fired by denouncing the poor working conditions of the employees in her report. Like Sarah, she experiences relief when taking off her corporate suit as if embracing her true self. She becomes a victim of the system by joining the high rates of unemployment in the Spanish economy, yet she decides to take revenge by denouncing the situation to the press so that her sacrifice is not in vain. She, therefore, goes a step further than her counterpart in Margin Call: she refuses to perform the gendered roles imposed on women in financial crisis films and takes the role of an active heroine carrying out an investigation as the main character in a corporate melodrama and avenging the deaths of her male colleagues. She thus crosses the borders of film genre and cinematic gender representation in this film cycle.

\section{Conclusion}

According to Walby, the two most likely alternative paths following the recession are 'intensified neoliberalism or reformed social democracy', both of them being 'gendered' projects linked to 'masculine' and 'feminine' social and culturally constructed values, which have been cleverly portrayed in the films analysed. In spite of the different socioeconomic and cultural contexts they depict, both cinematic productions are transnationally connected in their representation of the corporate world in recessionary times. Both films present the financial and business elite as an omnipotent overclass in control of the system. Top executives and middle managers are shown to base their individualistic actions on the TINA discourses. Nevertheless, despite its nihilistic ending, Margin Call manages to denounce the dehumanization of the financial and business world by showing a group of characters who surrender to the allures of their privileged status instead of acting as heroes to prevent the social ills provoked by unrestrained financial deregulation. The film deconstructs the 'mancession' discourse of the first years of the crisis by showing the only woman in the film unable to break the glass ceiling and becoming the 
scapegoat to save the company's image. It also subverts the gendered discourses of late capitalism by showing the 'neoliberal-patriarchal values' tandem attached to the business world in a negative light as they prove to be damaging for society. Sarah is symbolically relieved when she gets rid of her 'masculinised' masquerade. She does not, however, engage in an intersectional feminist fight against the oppressive patriarchal cum neoliberal discourses.

Like Sarah, Sofia, in The Tip of the Iceberg, is shown to be uncomfortable when playing a 'masculinised' role in the company. Set in the context of the austerity crisis, the film deals with the impact of the recession on the population by highlighting the close relationship between the suicide problem and the physical and psychological vulnerability suffered by the Spanish population at large. Released in 2016, The Tip of the Iceberg contains the seeds of the intersectional feminist movements that sprang up globally with the Women Marches in 2017 and specifically in Spain with the feminist strikes the following years, which called for a collective action against the oppression felt by vulnerable groups hit by the crisis in a (post)recessionary scenario.

In spite of their contextual differences, both films show a transnational common critique of the postfeminist-neoliberal tandem. They establish a dichotomy of death, artificiality and individualism, on the one hand, and life, nature and community, on the other, by symbolically opposing the cold corporate building with warm homely spaces. Both films, therefore, end up subverting the TINA discourses by privileging the 'feminine' values of care and community over those of entrepreneurship and competition, thus opening up a window for an 'alternative' path.

\section{Acknowledgements}

I would like to thank Celestino Deleyto and Enrique Tejero for their helpful comments on the draft of this paper.

\section{Funding}

The author(s) disclosed receipt of the following financial support for the research, authorship and/ or publication of this article: Research towards the writing of this article has been partially funded by the Aragonese Government, project no. H12, the Ministry of Economy, Industry and Competitiveness, project no. FFI2017-82312-P; the University of Zaragoza project no. JIUZ-2017-HUM-02.

\section{ORCID ID}

Elena Oliete-Aldea (iD https://orcid.org/0000-0001-8197-1199

\section{Notes}

1. The concept of 'crisis' as a 'turning point' recalls the Greek origins of the term, meaning selection, decision, judgement (Koselleck, 2002).

2. See also Berlant (2011); Mirowski (2013); Roitman (2016); Runciman (2016).

3. Following Walby's theory of the crisis as 'gendered', the term 'gender' is also defined here not as a fixed 'essential' identity but as a culturally constructed set of social relations to be understood within its specific historical and socio-economic conjuncture. 
4. For a detailed account of blogs and press articles which engaged in the 'mancession' discussion, see Peterson (2012); Negra and Tasker $(2013,2014)$.

5. In 2011, a reform of the Spanish Constitution prioritized the payment of the public debt over the need to issue further debt to fund the needs of the welfare state.

6. For analyses on gender wage gap and unemployment in Spain during the recession, see Murillo Huertas and Simón Pérez (2014); Nuño (2009); San José-Serrán (2015); Anghel et al. (2018).

7. Real Decreto Ley $3 / 2012$ de 10 de Febrero de Medidas Urgentes para la Reforma Laboral.

8. In 2008, there were 3 million public employees in the Spanish national territory, from which 1.3 million were men and 1.6 million were women (Instituto Nacionalde Estadística (INE), 2018).

9. For an overview of this cycle and specific analyses of the films, see Boyle and Mrozowski (2013); Negra and Tasker (2014), Allbritton (2014); Bardan (2013); Hellín and Talaya (2017); Oliete-Aldea (2018).

10. Some economists describe the 'Great Recession' as a double-dip recession, which started in 2007 and lasted until 2012 (Rosenberg, 2012).

11. For a detailed comparison between Wall Street and Money Never Sleeps, see Oliete-Aldea (2012).

12. The choice of Demi Moore for the part cannot but hint at Disclosure (Levinson, 1994), where the traditional aggressive-passive gender roles in the business environment were reversed.

13. Only Smoking Room (Wallovits and Gual, 2002), The method (El método, Piñeiro, 2005) and The Contestant (el concursante, Cortés, 2007) are the few Spanish films that tackle economic and business issues.

14. The suicide rate in Spain increased dramatically during the recession mainly due to the foreclosures imposed by the banks (Roberts, 2012).

\section{References}

Allbritton D (2014) Prime risks: The politics of pain and suffering in Spanish crisis cinema. Journal of Spanish Cultural Studies 15(1-2): 101-115.

Alonso LE, Rodríguez CJF and Rojo RI (2016) Entre la austeridad y el malestar: discursos sobre consumo y crisis económica en España. Reis: Revista Española de Investigaciones Sociológicas 155: 21-36.

Anghel B, Conde-Ruiz JI and Marra de Artiñano, I (2018). Brechas salariales de Género en España. Madrid: FEDEA. Available at: http://documentos. fedea. net/pubs/eee/eee2018-06. pdf. (accessed 13 February 2019)

Arruzza C, Bhattacharya T and Fraser N (2019) Feminism for the 99\% A Manifesto. London and New York: Verso.

Bardan A (2013) The New European cinema of precarity: A transnational perspective. In: Mazierska E (ed.) Work in Cinema. Labor and the Human Condition. Houndmills: Palgrave, pp.69-90.

Bauman Z and Bordoni C (2014) State of Crisis. Cambridge; Malden, MA: Polity Press.

Beale L (2010) Recession-themed films? Not at the multiplex. Los Angeles Times, 7 November. Available at: https://www.latimes.com/archives/la-xpm-2010-nov-07-la-ca-recession-movies-20101107-story.html (accessed 8 October 2019).

Berlant LG (2011) Cruel Optimism. London: Duke University Press.

Blinder S (2013) After the Music Stopped: The Financial Crisis, the Response and the Work Ahead. New York: The Penguin Press.

Boyle K and Mrozowski D (2013) The Great Recession in Fiction, Film and Television. TwentyFirst Century Bust Culture. Lanham, MD; Plymouth: Lexington Books. 
Coontz S (2012) The myth of male decline. New York Times, 29 September. Available at: https:// www.nytimes.com/2012/09/30/opinion/sunday/the-myth-of-male-decline.html

Crouch C (2011) The Strange Non-Death of Neo-Liberalism. Cambridge: Polity Press.

De Espinola Salazar JR (2009) En torno a la crisis económica en España. Revista Icade 77: 7-37.

Dolado JJ (2012) The pros and cons of the latest labour market reform in Spain. Spanish Labour Law and Employment Relations Journal 1(1-2): 22-30.

Faludi S (2006) Backlash: The Undeclared War Against American Women. London: Vintage Books.

García Delgado JL and Myro R (eds) (2014) The Spanish Economy. An Introduction. Pamplona: Aranzadi.

Gill R (2017) The affective, cultural and psychic life of postfeminism: A postfeminist sensibility 10 years on. European Journal of Cultural Studies 20(6): 606-626.

Hellín MJ and Talaya H (2017) El cine de la crisis. Respuestas cinematográficas a la crisis económica española en el siglo XXI. Barcelona: UOC.

Ho K (2009) Liquidated. An Ethnography of Wall Street. Durham and London: Duke University Press.

Ho K (2018) Finance, crisis and Hollywood: Critique and recuperation of Wall Street in films about the Great Recession. In: Parvulescu C (ed.) Global Finance on Screen: From Wall Street to Side Street. London; New York: Routledge, pp.89-104.

Instituto Nacionalde Estadística (INE) (2018) Asalariados por tipo de sector (público o privado), sexo y comunidad autónoma. Available at: https:/www.ine.es/jaxiT3/Tabla. htm?t=4960\&L=0 (accessed 4 December 2018).

Kinkle J and Toscano A (2011) Filming the crisis: A survey. Film Quarterly 65(1): 39-41.

Klein N (2017) No Is Not Enough. London: Penguin.

Koselleck R (2002) The Practice of Conceptual History. Timing History, Spacing Concepts. Stanford, CA: Stanford University Press.

Lombardo E (2017) Austerity politics and feminist struggles in Spain: Reconfiguring the gender regime? In: Kantola J, Lombardo E (eds) Gender and the Economic Crisis in Europe: Politics, Institutions and Intersectionality. Cham: Palgrave Macmillan.

Luyendijk J (2015) Swimming with Sharks: Inside the World of Bankers. London: Guardian Books.

McRobbie A (2009) The Aftermath of Feminism: Gender, Culture and Social Change. London: Sage.

Mirowski P (2013) Never Let a Serious Crisis Go Waste: How Neoliberalism Survived the Financial Meltdown. London: Verso.

Murillo Huertas IP and Simón Pérez HJ (2014) La Gran Recesión y el diferencial salarial por género en España. Hacienda Pública Española/Review of Public Economics 208: 39-76.

Negra D and Tasker Y (2013) Neoliberal frames and genres of inequality: Recession-era chick flicks and male-centred corporate melodrama. European Journal of Cultural Studies 16(3): 344-361.

Negra D and Tasker Y (2014) Gendering the Recession. Media and Culture in the Age of Austerity. Durham, NC; London: Duke University Press.

Nuño L (2009) El empleo femenino en España y en la Unión Europea. Revista de Investigaciones Feministas 1: 205-232.

Oliete-Aldea E (2012) Fear and nostalgia in times of crisis: The paradoxes of globalization in Oliver Stone's Money Never Sleeps. Culture Unbound 4: 347-366.

Oliete-Aldea E (2018) Global financial crisis in local filmic scenarios: Transnational cinema of the great recession. In: Parvulescu C (ed.) Global Finance on Screen: From Wall Street to Side Street. London; New York: Routledge, pp.179-197. 
Organization for Economic Cooperation and Development (OECD) (2010) 'Mancession'? OECD Observer 278. Available at: http://oecdobserver.org/news/archivestory.php/ aid/3240/'mancession'.html (accessed 2 June 2018).

Parvulescu C (2018) Introduction. In: Parvulescu C (ed.) Global Finance on Screen: From Wall Street to Side Street. London; New York: Routledge, pp.1-16.

Peterson J (2012) The great crisis and the significance of gender in the U.S. economy. Journal of Economic Issues 42(2): 277-290.

Real Decreto Ley 3/2012 de 10 de Febrero de Medidas Urgentes para la Reforma Laboral.

Rivers N (2017) Postfeminism(s) and the Arrival of the Fourth Wave. Houndmills: Palgrave Macmillan.

Roberts M (2012) Spanish banks to restrict evictions after suicides. The Guardian, 12 November. Available at: https://www.theguardian.com/world/2012/nov/12/spanish-banks-evictions-suicides (accessed 10 January 2017).

Roitman J (2016) The stakes of crisis. In: Kjaer PF and Olsen N (eds) Critical Theories of Crisis in Europe From Weimar to the Euro. London; New York: Rowan and Littlefield, pp.17-34.

Rosenberg JM (2012) The Concise Encyclopedia of the Great Recession 2007-2012. Lanham, Toronto and Plymouth: Scarecrow Press.

Rosin H (2010) The end of men. The Atlantic, July/August. Available at: https://www.theatlantic. com/magazine/archive/2010/07/the-end-of-men/308135/ (accessed 8 May 2018).

Runciman D (2016) What time frame makes sense for thinking about crises? In: Kjaer PF and Olsen N (eds) Critical Theories of Crisis in Europe From Weimar to the Euro. London; New York: Rowan and Littlefield, pp.3-16.

San José-Serrán B (2015) Igualdad versus Austeridad: Resistencia, protestas y propuestas del movimiento feminista. Investigaciones Feministas 5: 185-206.

Tasker Y (1998) Working Girls: Gender and Sexuality in Popular Cinema. London; New York: Routledge.

Thouaille MA (2018) Post-feminism at an impasse? The woman author heroine in postrecessionary American film. Feminist Media Studies 19: 495-509.

Tooze A (2018) Crashed: How a Decade of Financial Crises Changed the World. New York: Viking.

Walby S (2015) Crisis. Cambridge; Malden, MA: Polity Press.

\section{Biographical note}

Elena Oliete-Aldea, PhD, is senior lecturer at the Department of English and German Philology of the University of Zaragoza. Her current research centres on film genre and cultural studies, more concretely on filmic representations of cultural identities, especially international relationships in terms of class, gender and ethnicity, in the context of globalization and the current economic crisis in contemporary transnational cinema. Her recent publications include a monograph on British Raj Revival films Hybrid Heritage on Screen: The Raj Revival in the Thatcher Era, Hampshire: Palgrave Macmillan, 2015, and she has co-edited a book on transnational Spanish cinema Global Genres-Local Films: The Transnational Dimension of Spanish Cinema, New York: Bloomsbury, 2015. She has also published in international journals such as Studies in Spanish \& Latin American Cinemas, Journal of Popular Culture, Culture Unbound and book chapters in Routledge, Bloomsbury and Peter Lang, among others. She belongs to the research group 'Cinema, Culture and Society' (http://ccs.filmculture.net) and has been a member of several European and Spanish research projects. 